\title{
Lactobacillus taiwanensis sp. nov., isolated from silage
}

\author{
Li-Ting Wang, Hsiao-Ping Kuo, Yen-Chi Wu, Chun-Ju Tai \\ and Fwu-Ling Lee
}

\author{
Correspondence \\ Fwu-Ling Lee \\ fll@firdi.org.tw
}

\begin{abstract}
Bioresource Collection and Research Center, Food Industry Research and Development Institute, PO Box 246, Hsinchu 30099, Taiwan, ROC
\end{abstract}

\begin{abstract}
Strain FIRDI $006^{\top}$, isolated from silage cattle feed, was characterized by using phenotypic and molecular taxonomic methods. The strain was a homofermentative lactic acid bacterium; the cells stained Gram-positive and were catalase-negative, non-motile, facultatively anaerobic rods. 16S rRNA gene sequence analysis revealed that the strain belongs phylogenetically to the genus Lactobacillus and can be placed within the Lactobacillus acidophilus-delbrueckii group.

Lactobacillus gasseri and Lactobacillus johnsonii were the most closely related species, with 16S rRNA gene sequence similarities of 99.53 and $99.46 \%$ to the respective type strains. Low gyr $B$ gene sequence similarities $(<90 \%)$ and low DNA-DNA reassociation values $(<45 \%)$ were obtained between the strain and the phylogenetically closest neighbours. Based on phenotypic and genetic evidence, the strain is considered to represent a novel species, for which the name Lactobacillus taiwanensis sp. nov. is proposed. The type strain is FIRDI $006^{\top}\left(=\mathrm{BCRC} 17755^{\top}\right.$ $=$ DSM $21401^{\top}$ ).
\end{abstract}

Lactobacillus acidophilus is a Gram-positive, non-sporulating, rod-shaped, catalase-negative, non-motile, homofermentative and facultatively anaerobic bacterium (Hansen \& Mocquot, 1970). Its health benefits make it one of the most important probiotic species (Metchnikoff, 1908; Huis in't Veld, 1992; Ferencik et al., 2000; Taranto et al., 2004). The Lactobacillus acidophilus species group is composed of L. acidophilus and its phylogenetically closest relatives (Felis \& Dellaglio, 2007; Naser et al., 2007). Some of these species are quite difficult to distinguish by phenotypic characteristics, but can be differentiated by DNA-DNA hybridization, gene sequence analysis and DNA typing (Johnson et al., 1980; Lauer et al., 1980; Berger et al., 2007; Naser et al., 2007). A polyphasic taxonomic study of the members of the L. acidophilus species group and a novel strain, FIRDI $006^{\mathrm{T}}$, was performed using phenotypic characterization and phylogenetic and genetic methods. The results of this study consistently indicate that strain FIRDI $006^{\mathrm{T}}$ represents a novel Lactobacillus species.

Strain FIRDI $006^{\mathrm{T}}$ was isolated from silage cattle feed taken from Jhunan, Miaoli, Taiwan in 2006. For isolation of strain FIRDI $006^{\mathrm{T}}$, a $10 \mathrm{~g}$ forage sample was diluted in

The GenBank/EMBL/DDBJ accession numbers for the 16S rRNA and gyrB gene sequences of strain BCRC $17755^{\top}\left(=\mathrm{FIRDI} 006^{\top}\right)$ are respectively EU487512 and EU647675.

Neighbour-joining and maximum-parsimony phylogenetic trees based on 16S rRNA and gyrB gene sequences of the novel strain and related species and detailed results of DNA-DNA hybridization studies are available as supplementary material with the online version of this paper.
MRS broth, plated onto MRS agar (Difco) and incubated at $37{ }^{\circ} \mathrm{C}$ for $2-3$ days under anaerobic conditions (Genbox anaer; bioMérieux). Morphologically distinct single colonies that developed were picked up and restreaked onto the same medium at least twice before being considered pure. The pure strain was stored long-term at $-80{ }^{\circ} \mathrm{C}$ in MRS broth containing $20 \%(\mathrm{v} / \mathrm{v})$ glycerol or preserved by lyophilization. In addition to strain FIRDI $006^{\mathrm{T}}$, the reference strains L. acidophilus BCRC $10695^{\mathrm{T}}$, Lactobacillus helveticus BCRC $12936^{\mathrm{T}}$, Lactobacillus crispatus BCRC $14618^{\mathrm{T}}$, Lactobacillus gasseri BCRC $14619^{\mathrm{T}}$, Lactobacillus amylovorus BCRC $11648^{\mathrm{T}}$, Lactobacillus johnsonii $\mathrm{BCRC} 17474^{\mathrm{T}}$, Lactobacillus gallinarum $\mathrm{BCRC} 17266^{\mathrm{T}}$, Lactobacillus amylolyticus BCRC $17497^{\mathrm{T}}$ and Lactobacillus kitasatonis BCRC $17512^{\mathrm{T}}$ were selected for further comparative study.

Chromosomal DNA was isolated using the Qiagen Blood \& Cell Culture DNA kit. The 16S rRNA gene sequence was amplified by PCR and sequenced using the MicroSeq Full Gene 16S rDNA Bacterial Identification kit (Applied Biosystems). Sequencing was performed with a 3730 DNA sequencer (Applied Biosystems and Hitachi). Sequence assembly was performed using the ABI PRISM DNA Sequencing Analysis software (PE Applied Biosystems). Sequence similarity was calculated using the EzTaxon server (http://www.eztaxon.org/; Chun et al., 2007). The sequences obtained in this study and from GenBank were aligned using the CLUSTAL_X program, version 1.8 (Thompson et al., 1997), and phylogenetic trees were constructed with the neighbour-joining, maxi- 


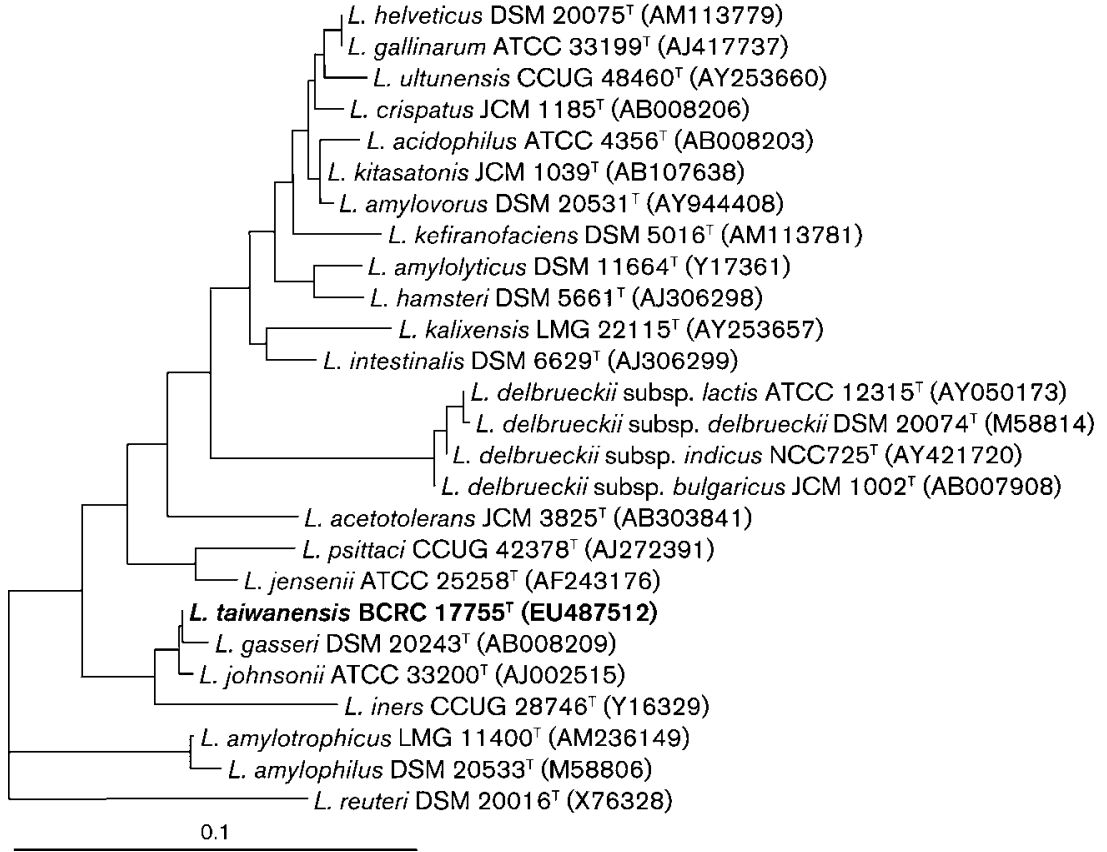

Fig. 1. Maximum-likelihood tree based on $16 \mathrm{~S}$ rRNA gene sequences of Lactobacillus strains. Bar, $10 \%$ nucleotide substitutions. mum-parsimony and maximum-likelihood methods using the PHYLIP computer program package (Felsenstein, 2005). Sequence distances were calculated by the F84 model (Felsenstein, 1984). Bootstrap analysis was made with 1000 replicates (Fig. 1 and Supplementary Figs S1 and S2, available in IJSEM Online). Tree figures were drawn by TreeView. The results of the phylogenetic analysis indicated that strain FIRDI $006^{\mathrm{T}}$ belongs to the genus Lactobacillus and is closely related to the Lactobacillus acidophilus-delbrueckii group (Fig. 1). It has been reported that six genome clusters (A1-A4, B1 and B2) exist within the L. acidophilus species group (Johnson et al., 1980; Lauer et al., 1980). Homology groups B1 and B2 were designated L. gasseri and L. johnsonii by Lauer \& Kandler (1980) and Fujisawa et al. (1992). Strain FIRDI $006^{\mathrm{T}}$ was included in a monophyletic cluster that contained L. gasseri and $L$. johnsonii. The highest levels of sequence similarity were with the type strains of L. gasseri (99.53\%) and L. johnsonii $(99.46 \%)$. The lowest level of sequence similarity was with the type strain of Lactobacillus iners (95.14\%).

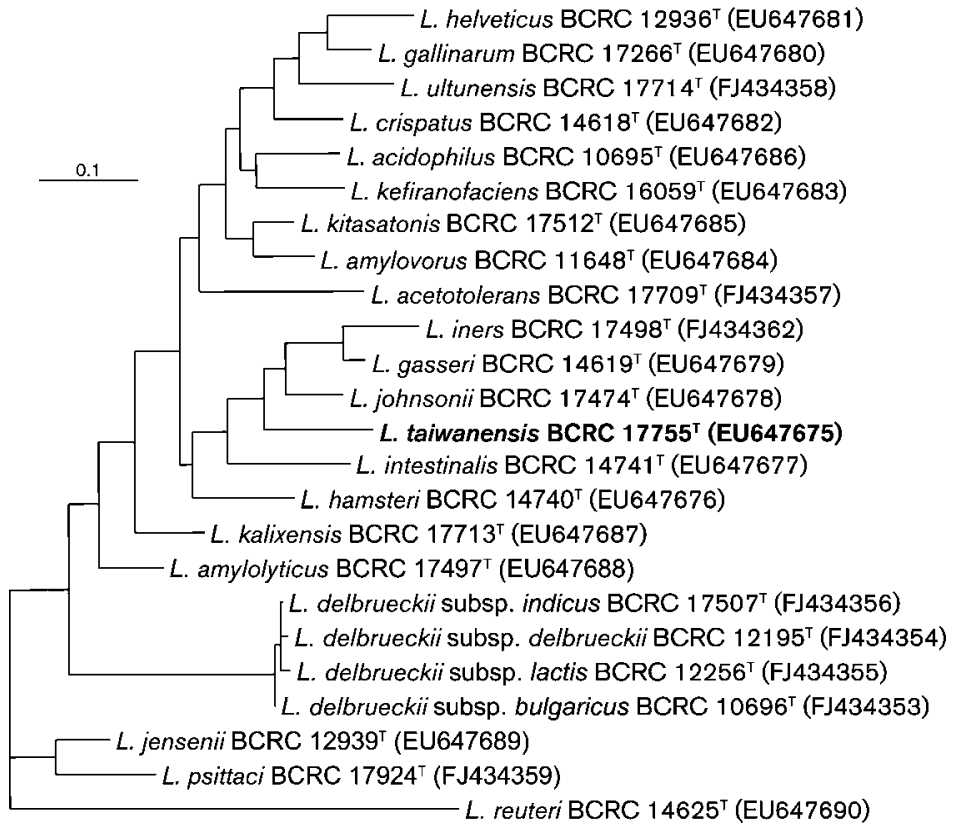

http://ijs.sgmjournals.org

L. reuteri BCRC $14625^{\top}$ (EU647690)
Fig. 2. Maximum-likelihood tree based on gyrB gene sequences of Lactobacillus strains. Bar, $10 \%$ nucleotide substitutions. 
To differentiate further between strain FIRDI $006^{\mathrm{T}}$ and closely related species, the partial sequence for the gene encoding the subunit B protein of DNA gyrase $(g y r B)$ was included in the phylogenetic analysis for comparative purposes. The gyrB gene was amplified by PCR as described previously (Yamamoto \& Harayama, 1995). The PCR was performed using a Taq DNA polymerase kit (Invitrogen). PCR products were purified with the PCR-M clean up system (Viogene) and sequenced with a BigDye Terminator v3.1 cycle sequencing kit (Applied Biosystems). DNA sequencing was determined using degenerate $\operatorname{gyr} B$ primers for strain FIRDI $006^{\mathrm{T}}, \mathrm{UP}-1 \mathrm{~S}$ and LA900R (5'CCTGGCAARTTDGCAATTTC- $3^{\prime}$ ) and, for other related Lactobacillus species, primers UP-1S, LA900R and UP-2Sr (Yamamoto \& Harayama, 1995). Sequence similarity was calculated using the program EMBOSS-Align (Needleman-
Wunsch global alignment) (http://www.ebi.ac.uk/). Using the method described above, the sequences obtained in this study were also aligned and phylogenetic trees were constructed (Fig. 2 and Supplementary Figs S3 and S4). The tree based on $777 \mathrm{bp}$ gyrB gene sequences showed clearly that strain FIRDI $006^{\mathrm{T}}$ formed a branch. Strain FIRDI $006^{\mathrm{T}}$ shared 87.15 and $90.09 \%$ similarity with $L$. johnsonii BCRC $17474^{\mathrm{T}}$ and L. gasseri BCRC $14619^{\mathrm{T}}$, whereas the similarities between strain FIRDI $006^{\mathrm{T}}$ and other members of the related cluster were less than $83 \%$. The $\operatorname{gyrB}$ gene sequence was a reliable indicator that the isolate was significantly differentiated from $L$. johnsonii and L. gasseri.

DNA $\mathrm{G}+\mathrm{C}$ contents and DNA-DNA relatedness were determined as described previously (Tamaoka \&

Table 1. Differentiating characteristics for strain FIRDI $006^{\top}$ (Lactobacillus taiwanensis sp. nov.) and its phylogenetically closest relatives

Strains: 1, FIRDI $006^{\mathrm{T}}$ (L. taiwanensis sp. nov.); 2, L. johnsonii BCRC $17474^{\mathrm{T}}$; 3, L. gasseri BCRC $14619^{\mathrm{T}}$; 4, L. acidophilus BCRC $10695^{\mathrm{T}}$; 5 , L. crispatus BCRC $14618^{\mathrm{T}} ; 6$, L. helveticus $\mathrm{BCRC} 12936^{\mathrm{T}}$; 7, L. gallinarum $\mathrm{BCRC} 17266^{\mathrm{T}} ; 8$, L. amylovorus $\mathrm{BCRC} 11648^{\mathrm{T}}$; 9 , L. kitasatonis BCRC $17512^{\mathrm{T}}$; 10, L. amylolyticus BCRC $17497^{\mathrm{T}}$. DNA G + C contents for L. gallinarum, L. amylovorus and L. kitasatonis are ranges for several strains taken from Mukai et al. (2003); other data were obtained in this study. All strains grew at $45{ }^{\circ} \mathrm{C}$ and at $\mathrm{pH} 6.5$ and 8.0. All strains grew in medium with $2 \%$ $\mathrm{NaCl}$, but not with $7 \% \mathrm{NaCl}$. None of the strains produced gas from glucose. All strains produced acid from D-glucose, D-fructose and maltose. None of the strains produced acid from D- or L-arabinose, D- or L-fucose, D-lyxose, melezitose, L-rhamnose, D-ribose, L-sorbose, turanose, D- or Lxylose, inulin, D-adonitol, D- or L-arabitol, dulcitol, erythritol, glycerol, inositol, D-mannitol, D-sorbitol, xylitol, methyl $\alpha$-D-glucopyranoside, methyl $\alpha$-D-mannopyranoside, methyl $\beta$-D-xylopyranoside, potassium gluconate, potassium 2-ketogluconate or potassium 5-ketogluconate.

\begin{tabular}{|c|c|c|c|c|c|c|c|c|c|c|}
\hline Characteristic & 1 & 2 & 3 & 4 & 5 & 6 & 7 & 8 & 9 & 10 \\
\hline \multicolumn{11}{|l|}{ Growth in MRS broth at/in: } \\
\hline $15{ }^{\circ} \mathrm{C}$ & - & + & - & - & - & - & - & - & - & - \\
\hline $\mathrm{pH} 4.0$ & + & + & + & - & + & - & - & + & + & + \\
\hline $5 \% \mathrm{NaCl}$ & + & + & + & - & - & - & - & - & - & - \\
\hline Gas production from gluconate & - & - & + & + & - & - & - & - & - & - \\
\hline \multicolumn{11}{|l|}{ Acid production from: } \\
\hline D-Galactose & + & + & + & - & - & + & + & + & + & - \\
\hline D-Mannose & + & + & + & + & - & + & + & + & - & + \\
\hline$N$-Acetylglucosamine & - & + & + & + & + & + & + & + & + & + \\
\hline Amygdalin & - & - & + & + & + & - & + & - & - & - \\
\hline Arbutin & - & - & + & - & - & - & - & + & - & - \\
\hline Aesculin & + & + & + & + & + & - & + & + & + & - \\
\hline Salicin & - & - & + & + & + & - & + & + & - & - \\
\hline Cellobiose & - & - & + & + & + & - & + & + & + & - \\
\hline Lactose & + & + & + & + & + & + & + & - & - & - \\
\hline Melibiose & - & - & - & - & - & - & + & - & - & - \\
\hline Sucrose & + & + & + & + & + & - & + & + & + & + \\
\hline Trehalose & + & - & + & + & - & + & - & + & - & - \\
\hline Raffinose & - & + & - & - & - & - & + & - & - & - \\
\hline Starch & + & + & + & - & + & - & + & + & + & - \\
\hline Glycogen & - & - & - & - & + & - & + & + & - & - \\
\hline Gentiobiose & + & + & + & + & - & - & + & + & + & - \\
\hline D-Tagatose & - & + & + & - & - & - & - & - & - & - \\
\hline DNA G + C content $(\mathrm{mol} \%)$ & 35.8 & 35.9 & 35.8 & 35.7 & 39.1 & 39.2 & $36-37$ & $36-38$ & $37-40$ & 40.1 \\
\hline \multicolumn{11}{|c|}{$\begin{array}{l}\text { Sequence similarity (\%) with respect } \\
\text { to strain FIRDI } 006^{\mathrm{T}}\end{array}$} \\
\hline 16S rRNA gene & $(100)$ & 99.46 & 99.53 & 92.54 & 92.67 & 93.00 & 93.14 & 92.34 & 92.56 & 92.34 \\
\hline gyrB & $(100)$ & 87.15 & 90.09 & 82.88 & 81.21 & 81.60 & 83.91 & 82.65 & 83.27 & 82.24 \\
\hline
\end{tabular}


Komagata, 1984; Ezaki et al., 1989; Goris et al., 1998; Wang et al., 2007). The DNA G $+\mathrm{C}$ content of strain FIRDI $006^{\mathrm{T}}$ was $35.8 \mathrm{~mol} \%$. This value is close to the values of 35.9 and $35.8 \mathrm{~mol} \%$ for L. johnsonii BCRC $17474^{\mathrm{T}}$ and L. gasseri BCRC $14619^{\mathrm{T}}$ (Table 1). Using labelled DNA of strain FIRDI $006^{\mathrm{T}}$ and $L$. johnsonii BCRC $17474^{\mathrm{T}}$, low levels of reassociation $(<45 \%)$ were observed with the type strains of closely related Lactobacillus species and subspecies (Supplementary Table S1). These values are well below the threshold of $70 \%$ that has been suggested for species delineation (Stackebrandt \& Goebel, 1994), indicating that strain FIRDI $006^{\mathrm{T}}$ represents a separate genomic species.

Morphological, physiological and biochemical characteristics of all strains were determined by using cells grown on MRS agar plates or in MRS broth for 2 days at $37{ }^{\circ} \mathrm{C}$ under anaerobic conditions. The characteristics of strain FIRDI $006^{\mathrm{T}}$ (described in detail in the species description) were compared with those of type strains of closely related species (Table 1). All of the strains grew at $45{ }^{\circ} \mathrm{C}$ but not at $15{ }^{\circ} \mathrm{C}$ except $L$. johnsonii BCRC $17474^{\mathrm{T}}$. Strain FIRDI $006^{\mathrm{T}}$, L. johnsonii BCRC $17474^{\mathrm{T}}$ and L. gasseri BCRC $14619^{\mathrm{T}}$ grew at $\mathrm{pH} 4.0,6.5$ and 8.0 and in medium containing 2 and $5 \%(\mathrm{w} / \mathrm{v}) \mathrm{NaCl}$. Strain FIRDI $006^{\mathrm{T}}$ did not produce gas from glucose or gluconate, as examined with Durham tubes; the absence of $\mathrm{CO}_{2}$ production could indicate either an obligately homofermentative or a facultatively heterofermentative metabolism (Hammes \& Vogel, 1995). Carbohydrate fermentation patterns were evaluated using the API 50 CHL system (bioMérieux) according to the manufacturer's instructions. The results were recorded after $48 \mathrm{~h}$ at $37^{\circ} \mathrm{C}$. All strains were found to display similar fermentation characteristics.

Based on the reported data, the phenotypic characteristics of the isolate were similar to those of its phylogenetically closest relatives, L. gasseri and L. johnsonii, and other homofermentative Lactobacillus species (Table 1). However, gyrB gene sequence similarity and DNA-DNA relatedness showed a clear separation of strain FIRDI $006^{\mathrm{T}}$ from its closest phylogenetic relatives. Thus, we propose the novel species Lactobacillus taiwanensis sp. nov. to accommodate strain FIRDI $006^{\mathrm{T}}$.

\section{Description of Lactobacillus taiwanensis sp. nov.}

Lactobacillus taiwanensis (tai.wa.nen'sis. N.L. masc. adj. taiwanensis of Taiwan, referring to the geographical origin of the type strain).

Cells are Gram-positive-staining, non-motile, non-sporeforming, catalase-negative rods, $0.5-1.0 \times 2.0-20.0 \mu \mathrm{m}$, occurring as single cells or in pairs or chains. Grows better at $37{ }^{\circ} \mathrm{C}$ than at $30{ }^{\circ} \mathrm{C}$. Colonies are approximately $2 \mathrm{~mm}$ in diameter, circular to slightly irregular, convex, opaque, rough and white after 2 days at $37{ }^{\circ} \mathrm{C}$ on MRS agar plates. Facultatively anaerobic and produces DL-lactic acid homofermentatively. In MRS broth, growth occurs at $45{ }^{\circ} \mathrm{C}$ but not at 15 or $50{ }^{\circ} \mathrm{C}$. Growth is observed in MRS broth containing 2 or $5 \%(\mathrm{w} / \mathrm{v}) \mathrm{NaCl}$ and at $\mathrm{pH} 4-8$. Acid is produced without gas formation from D-glucose, Dgalactose, D-fructose, D-mannose, maltose, lactose, sucrose, trehalose, gentiobiose, starch and aesculin. No acid formation from D- or L-arabinose, cellobiose, D- or Lfucose, D-lyxose, melibiose, melezitose, raffinose, D-ribose, L-rhamnose, L-sorbose, D-tagatose, turanose, D- or L-xylose, $\mathrm{N}$-acetylglucosamine, inulin, D-adonitol, D- or L-arabitol, dulcitol, erythritol, glycerol, inositol, D-mannitol, Dsorbitol, xylitol, glycogen, amygdalin, arbutin, salicin, methyl $\alpha$-D-glucopyranoside, methyl $\alpha$-D-mannopyranoside, methyl $\beta$-D-xylopyranoside, potassium gluconate, potassium 2-ketogluconate or potassium 5-ketogluconate. The DNA G + C content of the type strain is $35.8 \mathrm{~mol} \%$.

The type strain, FIRDI $006^{\mathrm{T}}\left(=\mathrm{BCRC} 17755^{\mathrm{T}}=\mathrm{DSM}\right.$ $\left.21401^{\mathrm{T}}\right)$, was isolated from silage cattle feed in Taiwan in 2006.

\section{Acknowledgements}

We thank T. Y. Liu, C. C. Liao and G. F. Yuan (Food Industry Research and Development Institute, Taiwan) for their encouragement. This research was supported by the Council of Agriculture, Executive Yuan, ROC [project no. 96AS-3.1.1-AD-U1(3)].

\section{References}

Berger, B., Pridmore, R. D., Barretto, C., Delmas-Julien, F., Schreiber, K., Arigoni, F. \& Brüssow, H. (2007). Similarity and differences in the Lactobacillus acidophilus group identified by polyphasic analysis and comparative genomics. J Bacteriol 189, 1311-1321.

Chun, J., Lee, J.-H., Jung, Y., Kim, M., Kim, S., Kim, B. K. \& Lim, Y. W. (2007). EzTaxon: a web-based tool for the identification of prokaryotes based on $16 \mathrm{~S}$ ribosomal RNA gene sequences. Int J Syst Evol Microbiol 57, 2259-2261.

Ezaki, T., Hashimoto, Y. \& Yabuuchi, E. (1989). Fluorometric deoxyribonucleic acid-deoxyribonucleic acid hybridization in microdilution wells as an alternative to membrane filter hybridization in which radioisotopes are used to determine genetic relatedness among bacterial strains. Int J Syst Bacteriol 39, 224-229.

Felis, G. E. \& Dellaglio, F. (2007). Taxonomy of lactobacilli and bifidobacteria. Curr Issues Intest Microbiol 8, 44-61.

Felsenstein, J. (1984). Distance methods for inferring phylogenies: a justification. Evolution 38, 16-24.

Felsenstein, J. (2005). PHYLIP (phylogeny inference package), version 3.65. Distributed by the author. Department of Genome Sciences, University of Washington, Seattle, USA.

Ferencik, M., Mikes, Z., Ebringer, L., Jahnova, E. \& Ciznar, I. (2000). Immunostimulatory and other beneficial health effects of lactic acid bacteria. Bratisl Lek Listy 101, 51-53 (in Slovak).

Fujisawa, T., Benno, Y., Yaeshima, T. \& Mitsuoka, T. (1992). Taxonomic study of the Lactobacillus acidophilus group, with recognition of Lactobacillus gallinarum sp. nov. and Lactobacillus johnsonii sp. nov. and synonymy of Lactobacillus acidophilus group A3 (Johnson et al. 1980) with the type strain of Lactobacillus amylovorus (Nakamura 1981). Int J Syst Bacteriol 42, 487-491.

Goris, J., Suzuki, K., De Vos, P., Nakase, T. \& Kersters, K. (1998). Evaluation of a microplate DNA-DNA hybridization method compared with the initial renaturation method. Can J Microbiol 44, $1148-1153$. 
Hammes, W. P. \& Vogel, R. F. (1995). The genus Lactobacillus. In The Genera of Lactic Acid Bacteria, pp. 19-54. Edited by B. J. B. Wood \& W. H. Holzapfel. London: Blackie Academic \& Professional.

Hansen, P. A. \& Mocquot, G. (1970). Lactobacillus acidophilus (Moro) comb. nov. Int J Syst Bacteriol 20, 325-327.

Huis in't Veld, J. H. (1992). The role of lactic acid bacteria in nutrition and health. Ned Tijdschr Tandheelkd 99, 467-471 (in Dutch).

Johnson, J. L., Phelps, C. F., Cummins, C. S., London, J. \& Gasser, F. (1980). Taxonomy of the Lactobacillus acidophilus group. Int J Syst Bacteriol 30, 53-68.

Lauer, E. \& Kandler, O. (1980). Lactobacillus gasseri sp. nov., a new species of the subgenus Thermobacterium. Zentralbl Bakteriol Mikrobiol Hyg 1 Abt Orig C 1, 75-78.

Lauer, E., Helming, C. \& Kandler, O. (1980). Heterogeneity of the species Lactobacillus acidophilus (Moro) Hansen and Mocquot as revealed by biochemical characteristics and DNA-DNA hybridization. Zentralbl Bakteriol Mikrobiol Hyg 1 Abt Orig C 1, 150-168.

Metchnikoff, E. (1908). Prolongation of Life. New York: Putnam.

Mukai, T., Arihara, K., Ikeda, A., Nomura, K., Suzuki, F. \& Ohori, H. (2003). Lactobacillus kitasatonis sp. nov., from chicken intestine. Int J Syst Evol Microbiol 53, 2055-2059.

Naser, S. M., Dawyndt, P., Hoste, B., Gevers, D., Vandemeulebroecke, K., Cleenwerck, I., Vancanneyt, M. \& Swings, J. (2007). Identification of lactobacilli by pheS and rpoA gene sequence analyses. Int J Syst Evol Microbiol 57, 2777-2789.

Stackebrandt, E. \& Goebel, B. M. (1994). Taxonomic note: a place for DNA-DNA reassociation and $16 \mathrm{~S}$ rRNA sequence analysis in the present species definition in bacteriology. Int J Syst Bacteriol 44, 846-849.

Tamaoka, J. \& Komagata, K. (1984). Determination of DNA base composition by reversed-phase high-performance liquid chromatography. FEMS Microbiol Lett 25, 125-128.

Taranto, M. P., Perdigon, G., Medici, M. \& De Valdez, G. F. (2004). Animal model for in vivo evaluation of cholesterol reduction by lactic acid bacteria. Methods Mol Biol 268, 417-422.

Thompson, J. D., Gibson, T. J., Plewniak, F., Jeanmougin, F. \& Higgins, D. G. (1997). The CLUSTAL_X windows interface: flexible strategies for multiple sequence alignment aided by quality analysis tools. Nucleic Acids Res 25, 4876-4882.

Wang, L. T., Lee, F. L., Tai, C. J., Yokota, A. \& Kuo, H. P. (2007), Reclassification of Bacillus axarquiensis Ruiz-García et al. 2005 and Bacillus malacitensis Ruiz-García et al. 2005 as later heterotypic synonyms of Bacillus mojavensis Roberts et al. 1994. Int J Syst Evol Microbiol 57, 1663-1667.

Yamamoto, S. \& Harayama, S. (1995). PCR amplification and direct sequencing of $g y r B$ genes with universal primers and their application to the detection and taxonomic analysis of Pseudomonas putida strains. Appl Environ Microbiol 61, 1104-1109. 